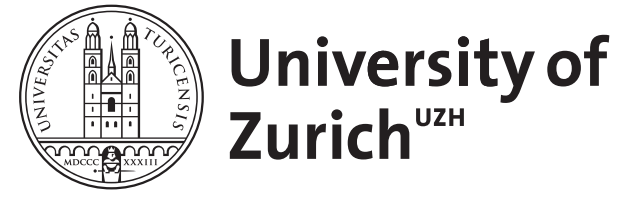

Zurich Open Repository and Archive

University of Zurich

University Library

Strickhofstrasse 39

CH-8057 Zurich

www.zora.uzh.ch

Year: 2007

\title{
Introduction to Symposium on Sports Economics
}

Dietl, Helmut ; Frick, Bernd

DOI: https://doi.org/10.1057/eej.2007.31

Posted at the Zurich Open Repository and Archive, University of Zurich

ZORA URL: https://doi.org/10.5167/uzh-52852

Journal Article

Published Version

Originally published at:

Dietl, Helmut; Frick, Bernd (2007). Introduction to Symposium on Sports Economics. Eastern Economic Journal, 33(3):376-377.

DOI: https://doi.org/10.1057/eej.2007.31 


\title{
INTRODUCTION TO SYMPOSIUM ON SPORTS ECONOMICS
}

\author{
Helmut Dietl \\ University of Zurich \\ and \\ Bernd Frick \\ University of Paderborn
}

The professional team sports industry is characterized by five major peculiarities. First, there are hardly any opportunities for productivity gains in this industry. On the output side, the number of championships that can be produced is limited. On the input side, the room for productivity gains is limited as well. In soccer, for example, clubs cannot increase their productivity by playing without their left defender even if this allowed their opponents to cut their right wing, eliminate one linesman, and so forth. Second, competition in professional team sports exhibits significant externalities. Since output in terms of team rankings is limited, each team cannot improve its output (ranking) without the externality of worsening the rank of at least one opponent. Third, there are probably more monopolies in professional team sports than in any other industry. Teams often enjoy local monopolies. Competing leagues usually do not survive for longer periods. Either one league becomes too dominant and drives out its competitors or the competing leagues merge to form a monopoly. Due to its peculiarities and perhaps its popularity, the professional team sports industry enjoys several exemptions from common antitrust regulations. For example, salary caps, transfer restrictions, and centralized marketing by league-monopolies would not be tolerated in other industries. These exceptions result in very interesting labor market peculiarities within professional team sports. Fourth, the so called uncertainty of outcome hypothesis suggests that competitive balance increases fan demand. In other industries, firms prefer weak competitors. In professional team sports, weak opponents cannot draw large crowds and are therefore economically unattractive. Fifth, professional team sports creates various satellite markets which may generate even larger revenues than the primary sports market. A typical example of such a satellite market is the betting market.

These peculiarities make the industry of professional team sports an interesting research field for economists. Since the industry is organized differently across the world and we even can often observe different institutional arrangements within a given country, professional team sports is an interesting source of natural experiments. Moreover, the industry is rich in easily accessible data.

This symposium of three selected papers has been assembled from two sessions on sports economics at the 2006 annual conference of the Eastern Economic Association in Philadelphia. The first paper by Brandes and Franck empirically analyzes the uncertainty of outcome hypothesis. According to this hypothesis, fan demand 
increases with competitive balance: the more balanced a league is the larger will be its overall attendance. Brandes and Franck estimate vector autoregressive models based on seasonal average attendance data in German, English, Italian and French professional football in the seasons $1963 / 64$ to 2005/06. Using an idealized standard deviation of winning percentages, the CR5 concentration ratio, and the Herfindahlindex, they find significant differences in the relationship between attendance and competitive balance across countries and even within countries across hierarchical leagues. Granger causality tests indicate that fan attendance does not necessarily react to changes in competitive balance. For Germany's first division and Italy's Serie A, for example, Brandes and Franck even find evidence that changes in fan demand determine the level of competitive balance. These results have important policy implications because many professional leagues have implemented a number of redistributive mechanisms (e.g., revenue sharing or reverse order drafts) in order to enhance competitive balance.

In the second paper, Dietl and Hasan compare the European and North American markets for sports broadcasting. In practically all major leagues around the world, income out of broadcasting rights has replaced gate receipts as the most important source of revenue. Based on a four-stage game-theoretical model, they identify three main determinants for the sale of sports broadcasting rights. First, free-TV networks are more likely to outbid their pay-TV competitors if the regulator imposes a less restrictive price cap on the free-TV network. This price cap is equivalent to a minimum quantity (in terms of the number of viewers) of sports broadcasting on free-TV. Second, major sports leagues are more likely to sell exclusive broadcasting rights to free-TV networks even if their bid is lower than the bid of their pay-TV rival given that the league's sponsorship income is highly sensitive to television viewer ratings. Third, major league sports is more likely to be aired on free-TV if viewers' demand is highly price elastic. These results are consistent with the empirical fact that TV coverage of professional football (soccer) in Europe has moved to subscription TV whereas major league team sports in the U.S. is aired primarily on free-TV. In the U.S., FCC legislation restricts the entrance of subscription-based networks. In addition, freeTV networks enjoy economies of scale due to the large national market. Moreover, competition between major team sports is much more pronounced in the U.S. than in Europe which results in a larger substitution effect and higher price elasticities of viewers and higher viewer rating sensitivity of sponsors.

In the third paper Frick, Pietzner, and Prinz analyze the labor market for soccer players in Germany. Based on detailed information for every single player who appeared in at least one match in Germany's top division between 1963 and 2003, Frick et al. study the determinants of career duration in professional team sports. Interestingly, more than one third of all players disappear after their first season and only one career out of twelve lasts for ten years or more. These results suggest that professional team sports is a short-term and high-risk career opportunity. As expected, the most important determinant of career duration is a player's performance. However, Frick et al. also find some evidence for discrimination of East European players. The data also provides opportunities for further research, such as testing of the Coase Theorem. 
Copyright of Eastern Economic Journal is the property of Eastern Economic Association and its content may not be copied or emailed to multiple sites or posted to a listserv without the copyright holder's express written permission. However, users may print, download, or email articles for individual use. 